\title{
Evaluation of NORM and Dose Assessment in an Aluminium Industry in Nigeria
}

\author{
Janet Ayobami Ademola*, Michael Adekunle Olatunji \\ Department of Physics, University of Ibadan, Ibadan, Nigeria \\ Email: ${ }^{*}$ jaaademola@yahoo.com
}

Received July 8, 2013; revised August 21, 2013; accepted September 8, 2013

Copyright (C) 2013 Janet Ayobami Ademola, Michael Adekunle Olatunji. This is an open access article distributed under the Creative Commons Attribution License, which permits unrestricted use, distribution, and reproduction in any medium, provided the original work is properly cited.

\begin{abstract}
The activity concentrations of natural radionuclides ${ }^{226} \mathrm{Ra},{ }^{232} \mathrm{Th}$ and ${ }^{40} \mathrm{~K}$ in bauxite ore, alumina, dross tailing, aluminium scraps and soil samples collected from an aluminium industry in Nigeria were determined by gamma ray spectroscopy method. The mean values of ${ }^{226} \mathrm{Ra},{ }^{232} \mathrm{Th}$ and ${ }^{40} \mathrm{~K}$ content of the samples ranged from $16 \pm 6$ (alumina) to $31 \pm 10$ (scrap), $41 \pm 0.12$ (scrap) to $134 \pm 21$ (bauxite) and $47 \pm 14$ (bauxite) to $354 \pm 8$ (scrap) Bq.kg ${ }^{-1}$, respectively. The mean activity concentrations of ${ }^{226} \mathrm{Ra}$ and ${ }^{40} \mathrm{~K}$ in all the samples are lower than the world average for soil while ${ }^{232} \mathrm{Th}$ is higher with the exception of alumina and scrap. As a measure of radiation hazard to the occupational workers and the members of the public, the radium equivalent activities and external gamma dose rates due to the radionuclides at $1 \mathrm{~m}$ above ground surface were calculated. The radium equivalent activities which varied between $88 \pm 10$ (alumina) and $222 \pm 34$ (bauxite) $\mathrm{Bq} \cdot \mathrm{kg}^{-1}$ are within the safety recommended limit of $370 \mathrm{~Bq} \cdot \mathrm{kg}^{-1}$. The mean annual effective doses calculated from the absorbed dose rates in air were between $54 \pm 6$ (alumina) and $134 \pm 20$ (bauxite) $\mu \mathrm{Sv} \cdot \mathrm{y}^{-1}$, which is lower than the $1 \mathrm{mSv} \cdot \mathrm{y}^{-1}$ recommended for the general public. The annual gonadal dose equivalent of all the samples with the exception of alumina was higher than the world average for soil.
\end{abstract}

Keywords: NORM; Gamma Radiation Dose; Radiation Hazards; Aluminium

\section{Introduction}

Natural radioactivity is a common phenomenon that is as old as the age of the planet earth. Radioactive elements occur naturally in rocks, soils and water in varying concentrations [1]. They give rise to a natural radiation background that varies by approximately two orders of magnitude over the surface of the earth, but in most situations this exposure is not amenable to control [1]. Most of the essentials of man come from the earth crust with the exception of air. Dependence on these essentials such as soil, water, rock and minerals poses some natural radiation treats to man.

Enhanced levels of naturally occurring radionuclides may be associated with certain natural materials, minerals and other resources. Exploitation of these resources for the production of consumer items may lead to further enhancement of the radioactivity at concentrations above normal in the products, by-products, residues or waste arising from the industrial process. Raw materials used in industries may contain naturally occurring radioactive

\footnotetext{
"Corresponding author.
}

materials (NORM). The most important are the ${ }^{238} \mathrm{U}$ and ${ }^{232} \mathrm{Th}$ and their decay products as well as ${ }^{40} \mathrm{~K}[2-5]$. The raw materials vary in activity concentrations depending on the region of origin [6]. The mining, transportation and processing of the raw materials may lead to the release of radionuclides into the environment and the distribution of the radionuclides in products and waste thereby giving rise to radiological hazards in workplaces and in the environment.

Aluminium is the most abundant metallic element and the third most abundant element in the earth's crust after oxygen and silicon [7]. The chief source of aluminium is bauxite ore which contains about $30 \%$ to $50 \%$ hydrated aluminium oxide $\left(\mathrm{Al}_{2} \mathrm{O}_{3} \cdot 2 \mathrm{H}_{2} \mathrm{O}\right.$ with some impurities like iron and clay). This may contain significant activity concentrations due to either or both ${ }^{238} \mathrm{U}$ and ${ }^{232} \mathrm{Th}$, depending on the ore mineralogy. As a result of this, aluminium industries are considered as industries with a potential radiological impact on people and the environment [810].

The Aluminium Smelter Company of Nigeria (AL$\mathrm{SCON}$ ) is the nation's premier smelter plant. It is located 
at Ikot-Abasi in Akwa Ibom State, in the southeastern part of Nigeria. Aluminium also occurs with other elements as silicates. Common silicates that contain aluminium are feldspar, muscovite mica, kaolin, fuller's carts etc. Even though kaolin is found in abundance in Benue State, the north-central of Nigeria as well as in Akwa Ibom State, the southern part of the country, the industry depends solely on imported raw materials (bauxite and alumina) for the production of aluminium. This is because the silicates are complex and not normally used for aluminium production and besides, the silicates are not economical because of the large contents of clay and iron haemitite in them.

Work activites in which radiation exposure of workers and members of the public is increased due to the presence of NORM are receiving attention from regulatory authorities. To the best of our knowledge, there is no study on radiological aspect of the aluminium industry in Nigeria. Therefore, the present study seeks to investigate the level of natural radionuclides in the raw materials used for the production of aluminium in Nigeria and soil samples from the surrounding area of the industry. The health effects that such radionuclides may have on the population are also assessed.

\section{Materials and Methods}

A total of forty-four samples were collected from ALSCON for this study. They include bauxite ore (4 samples), alumina (10 samples), dross tailing (14 samples), aluminium scraps (2 samples) and soil (14 samples). The soil samples were taken around the dross at distances of about $100 \mathrm{~cm}$ apart. The scrap samples were collected from the aluminium scraps obtained during production and processing of aluminium into other products like ingots and billet before it is recycled. Limited number of samples was collected due to restriction by the industry involved. The map of Nigeria showing the sampling spot is shown in Figure 1.

The samples were air dried and then oven dried. The dried samples were grinded in order to achieve homogenization; they were sieved through a $0.20 \mathrm{~mm}$ mesh sieve. A mass of $200 \mathrm{~g}$ each of the samples was weighed and packed into plastic container, hermetically sealed and stored for a minimum of one month before measurement. This is to prevent the escape of gaseous ${ }^{222} \mathrm{Rn}$ and ${ }^{220} \mathrm{Rn}$ from the samples and ensure the attainment of secular equilibrium [11].

The activity concentrations of the natural radionuclides were measured using a $7.6 \mathrm{~cm} \times 7.6 \mathrm{~cm} \mathrm{NaI(Tl)}$ detector (model No. 802-series) by Canberra Inc. The detector is coupled to series 10 plus Multi Channel Analyzer (MCA) (model No. 1104) through a preamplifier base. The detector is placed in a lead shield. The detector has a resolution of about $8 \%$ at $0.662 \mathrm{MeV}$ of ${ }^{137} \mathrm{Cs}$. This is

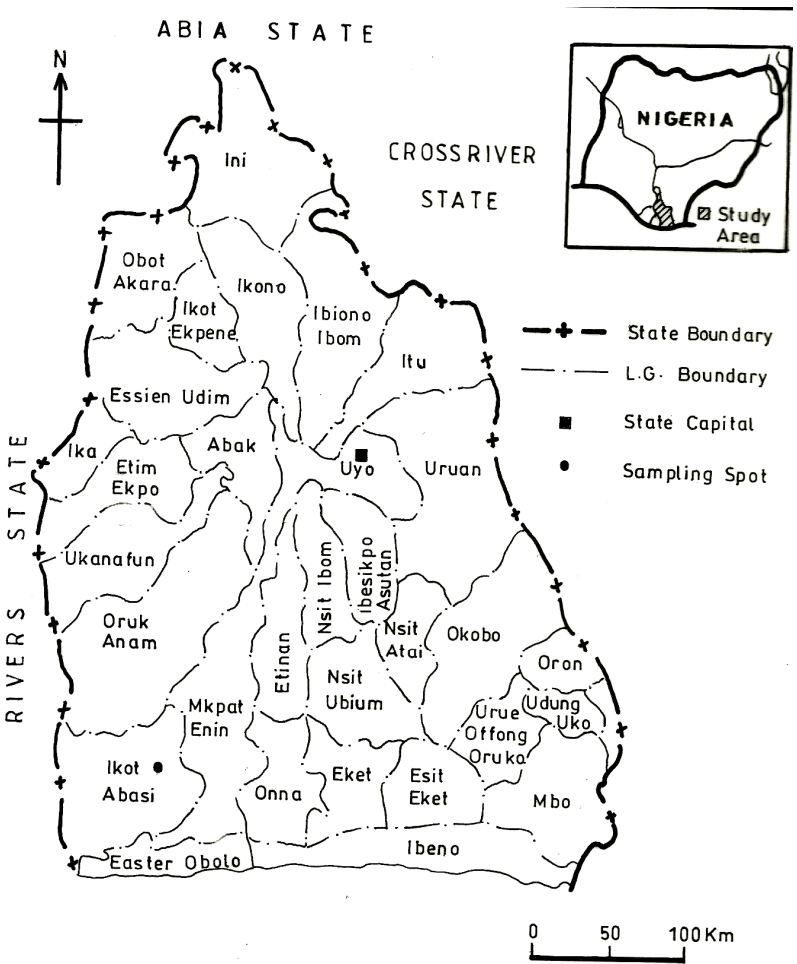

Figure 1. The map of Nigeria showing the sampling spot.

capable of distinguishing the gamma ray energies considered during measurements. The ${ }^{226} \mathrm{Ra}$ and ${ }^{232} \mathrm{Th}$ content were determined from the photopeaks of ${ }^{214} \mathrm{Bi}$ (1.764 $\mathrm{MeV})$ and ${ }^{208} \mathrm{Tl}(2.614 \mathrm{MeV})$, respectively. The potassium content of the sample was determined from photopeak of ${ }^{40} \mathrm{~K}(1.460 \mathrm{MeV})$. These peaks are clean, reasonably strong with very low continuum and were considered good enough because of poor resolution of the $\mathrm{NaI}(\mathrm{Tl})$ detector used in this work. The counting time for each sample was 10 hours.

Energy calibration was done to ensure that a relationship exist between the peak position of the spectrum and the corresponding gamma-ray energy. Energy calibration is achieved by measuring the spectrum of a source emitting gamma-rays of known energies and comparing the same with the measured peak positions. The calibration of the system was carried out using gamma sources of known energies for student laboratory experiments from Nucleus Inc., Oak Ridge, TN, USA. The peak area of each radionuclide was computed from the memory of the MCA using an algorithm which subtracts counts due to Compton scattering of higher peaks and other background effects from the total area.

For the calculation of individual radionuclide, the detection efficiency $E_{p}$ of the system was determined. The detection efficiency at the constant geometry of counting is defined as $[12,13]$;

$$
E_{p}=\frac{A}{t C Y m}
$$


where $A$ is the net area under the photopeak, $C\left(\mathrm{~Bq} \cdot \mathrm{kg}^{-1}\right)$ is the activity concentration of a reference sample of mass $\mathrm{m}(\mathrm{kg})$ counted for a time $t(\mathrm{~s})$ and $Y$ is the gamma radiation yield. The efficiency was determined using a reference source of known activity concentrations for each of the radionuclides prepared from Rocketdyne Laboratories, California USA, which is traceable to a mixed standard gamma source (No. 48772-356) by Analytic Inc., Atlanta, Georgia. The activity concentrations of each radionuclide in the samples were obtained by relating the detection efficiency to the net area under each photopeak.

\section{Results and Discussion}

The activity concentrations of ${ }^{226} \mathrm{Ra},{ }^{232} \mathrm{Th}$ and ${ }^{40} \mathrm{~K}$ are shown in Table 1. The mean activity concentrations range from $16 \pm 6$ (alumina) to $31 \pm 10$ (scrap), $41 \pm 0.1$ (scrap) to $134 \pm 21$ (bauxite) and $47 \pm 14$ (bauxite) to 354 \pm 8 (scrap) for ${ }^{226} \mathrm{Ra},{ }^{232} \mathrm{Th}$ and ${ }^{40} \mathrm{~K}$, respectively. The errors quoted are the standard deviations of the mean values. The mean activity concentrations of ${ }^{226} \mathrm{Ra}$ and ${ }^{40} \mathrm{~K}$ in all of the samples are less than the world average for soil, 33 and $420 \mathrm{~Bq} \cdot \mathrm{kg}^{-1}$, respectively while ${ }^{232} \mathrm{Th}$ is higher than the world average, $45 \mathrm{~Bq} \cdot \mathrm{kg}^{-1}$, with the exception of alumina and scrap [1]. Figure 2 presents a bar chat of the mean activity concentrations of the three radionuclides. Some reported concentration ranges of radioactivity in bauxite ore are given as $10-9000 \mathrm{~Bq} \cdot \mathrm{kg}^{-1}$ for uranium series radionuclides, $35-1400 \mathrm{~Bq} \cdot \mathrm{kg}^{-1}$ for thorium series radionuclides and $10-600 \mathrm{~Bq} \cdot \mathrm{kg}^{-1}$ for ${ }^{40} \mathrm{~K}$ [9]. Comparison of these with this study shows that the results obtained fall within the lower ranges.

The radiological risk was assessed by calculating the radium equivalent activity, the absorbed dose and the annual effective dose. The distribution of ${ }^{226} \mathrm{Ra},{ }^{232} \mathrm{Th}$ and ${ }^{40} \mathrm{~K}$ in samples are not uniform. To compare the activity concentrations and the radiological effect of the three radionuclides, a common index is used. The widely used index is the radium equivalent activity, $R a_{e q}[2,14]$. The $R a_{e q}$ had been defined assuming that $370 \mathrm{~Bq} \cdot \mathrm{kg}^{-1}$ of ${ }^{226} \mathrm{Ra}, 259 \mathrm{~Bq} \cdot \mathrm{kg}^{-1}$ of ${ }^{232} \mathrm{Th}$ and $4810 \mathrm{~Bq} \cdot \mathrm{kg}^{-1}$ of ${ }^{40} \mathrm{~K}$ produce the same gamma dose rate and is given as $[2,15,16]$;

$$
R a_{e q}=C_{\mathrm{Ra}}+1.43 C_{\mathrm{Th}}+0.077 C_{\mathrm{K}}
$$

where $C_{\mathrm{Ra}}, C_{\mathrm{Th}}$ and $C_{\mathrm{K}}$ are the activity concentrations of ${ }^{226} \mathrm{Ra},{ }^{232} \mathrm{Th}$ and ${ }^{40} \mathrm{~K}$ in $\mathrm{Bq} \cdot \mathrm{kg}^{-1}$, respectively. As far as radiological hazard is concerned, the safety criterion for materials containing these three radionuclides is 370 $\mathrm{Bq} \cdot \mathrm{kg}^{-1}$ [17]. The results obtained for $R a_{e q}$ are presented in Table 2. The mean values of the radium equivalent activity ranged from $88 \pm 10$ to $222 \pm 34 \mathrm{~Bq} \cdot \mathrm{kg}^{-1}$. These fall within the safety recommended limit of $370 \mathrm{~Bq} \cdot \mathrm{kg}^{-1}$.

The absorbed dose rate in air at a height of $1 \mathrm{~m}$ above the ground due to ${ }^{226} \mathrm{Ra},{ }^{232} \mathrm{Th}$ and ${ }^{40} \mathrm{~K}$ was calculated using the formula $[1,18]$;

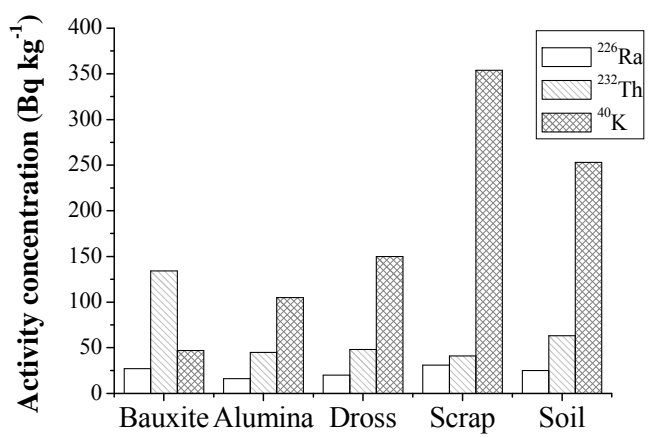

Figure 2. Mean activity concentrations of natural radionuclides in samples.

$$
\mathrm{D}\left(\mathrm{nGy} \cdot \mathrm{h}^{-1}\right)=0.462 C_{\mathrm{Ra}}+0.604 C_{\mathrm{Th}}+0.0417 C_{\mathrm{K}}
$$

where $C_{\mathrm{Ra}}, C_{\mathrm{Th}}$ and $C_{\mathrm{K}}$ are as defined in Equation (1). The mean absorbed dose rates due to the three radionuclides ranged from $39 \pm 5 \mathrm{nGy} \cdot \mathrm{h}^{-1}$ (alumina) to $95 \pm 4$ $n G y \cdot h^{-1}$ (bauxite). The mean absorbed dose rate for soil samples in the surroundings of the industry is $60 \pm 8$ $\mathrm{nGy} \cdot \mathrm{h}^{-1}$. This corresponds to the estimated world average value for soil $60 \mathrm{nGy} \cdot \mathrm{h}^{-1}$ [1]. All other samples had a mean value less than the world average except bauxite which had $95 \pm 14 \mathrm{nGy} \cdot \mathrm{h}^{-1}$.

The annual effective doses were calculated using a conversion coefficient of $0.7 \mathrm{~Sv} \cdot \mathrm{Gy}^{-1}$ for an absorbed dose in air to effective dose in human body [1]. The occupancy time was taken as the normal working hours in Nigeria which is 8 hours per day for five days in a week. For 50 working weeks per annum, the occupancy time is $2000 \mathrm{~h} \cdot \mathrm{y}^{-1}$. Hence, the annual effective dose, $H$, is

$$
\mathrm{H}=\mathrm{D} \times 10^{-9}\left(\mathrm{~Gy} \cdot \mathrm{h}^{-1}\right) \times 0.7 \mathrm{~Sv} \cdot \mathrm{Gy}^{-1} \times 2000 \mathrm{~h} \cdot \mathrm{y}^{-1}
$$

The average annual effective dose are $134 \pm 20,54 \pm 6$, $63 \pm 13,76 \pm 7$ and $84 \pm 11 \mu \mathrm{Sv} \cdot \mathrm{y}^{-1}$, respectively for bauxite, alumina, dross, scrap and soil. These are less than the $1 \mathrm{mSv} \cdot \mathrm{y}^{-1}$ recommended for the public (non exposed workers) [19].

The organs of interest considered by UNSCEAR (1988), are the gonads, the active bone marrow and the bone surface cells [20]. Hence the annual gonadal dose equivalent (AGDE), due the activity concentrations of ${ }^{226} \mathrm{Ra},{ }^{232} \mathrm{Th}$ and ${ }^{40} \mathrm{~K}$ in the samples was calculated using the following relation [21];

$$
\operatorname{AGDE}\left(\mu \mathrm{Sv} \cdot \mathrm{y}^{-1}\right)=3.09 C_{\mathrm{Ra}}+4.18 C_{\mathrm{Th}}+0.314 C_{\mathrm{K}}
$$

The mean values of the activity concentrations of ${ }^{226} \mathrm{Ra}$, ${ }^{232} \mathrm{Th}$ and ${ }^{40} \mathrm{~K}$ were used to calculate the AGDE. The results obtained (Table 2), show that the AGDE from all the samples with the exception of alumina are higher than the world average value of $0.30 \mathrm{mSv} \cdot \mathrm{y}^{-1}$ [21].

\section{Conclusion}

The activity concentrations of natural radionuclides in 
Table 1. Activity concentrations of natural radionuclides in samples.

\begin{tabular}{ccccccc}
\hline \multirow{2}{*}{ Sample } & \multicolumn{3}{c}{${ }^{226} \mathrm{Ra}$} & \multicolumn{3}{c}{${ }^{40} \mathrm{~K}$} \\
\cline { 2 - 7 } & Range & Mean \pm Std & Range & Mean \pm Std & Range & Mean \pm Std \\
\hline Bauxite (4) & $19-36$ & $27 \pm 7$ & $112-160$ & $134 \pm 21$ & $28-59$ & $47 \pm 14$ \\
Alumina (10) & $5-23$ & $16 \pm 6$ & $35-50$ & $45 \pm 4$ & $91-137$ & $105 \pm 16$ \\
Dross (14) & $7-55$ & $20 \pm 13$ & $40-61$ & $48 \pm 5$ & $118-193$ & $150 \pm 20$ \\
Scrap (2) & $24-38$ & $31 \pm 10$ & 41 & $41 \pm 0.12$ & $348-360$ & $354 \pm 8$ \\
Soil (14) & $16-35$ & $25 \pm 6$ & $54-80$ & $63 \pm 7$ & $152-442$ & $253 \pm 110$ \\
\hline
\end{tabular}

Table 2. Radium equivalent activity $\left(\mathrm{Ra}_{e q}\right)$, absorbed dose rate $(\mathrm{D})$ annual effective dose $(H)$ and annual gonadal dose equivalent (AGDE) of natural radionuclides in samples.

\begin{tabular}{|c|c|c|c|c|c|c|c|}
\hline \multirow{2}{*}{ Sample } & \multicolumn{2}{|c|}{$R a_{e q}\left(\mathrm{~Bq} \cdot \mathrm{kg}^{-1}\right)$} & \multicolumn{2}{|c|}{$D\left(\mathrm{nGy} \cdot \mathrm{h}^{-1}\right)$} & \multicolumn{2}{|c|}{$H\left(\mu \mathrm{Sv} \cdot \mathrm{y}^{-1}\right)$} & \multirow{2}{*}{$\operatorname{AGDE}\left(\mathrm{mSv} \cdot \mathrm{y}^{-1}\right)$} \\
\hline & Range & Mean \pm Std & Range & Mean \pm Std & Range & Mean \pm Std & \\
\hline Bauxite (4) & $189-262$ & $222 \pm 34$ & $81-112$ & $95 \pm 14$ & $114-157$ & $134 \pm 20$ & 0.66 \\
\hline Alumina (10) & $62-97$ & $88 \pm 10$ & $27-43$ & $39 \pm 5$ & $37-60$ & $54 \pm 6$ & 0.27 \\
\hline Dross (14) & $74-149$ & $101 \pm 20$ & $33-67$ & $45 \pm 9$ & $46-94$ & $63 \pm 13$ & 0.31 \\
\hline Scrap (2) & $109-124$ & $117 \pm 11$ & $50-58$ & $54 \pm 5$ & $71-81$ & $76 \pm 7$ & 0.38 \\
\hline Soil (14) & $116-177$ & $134 \pm 17$ & $52-80$ & $60 \pm 8$ & $72-112$ & $84 \pm 11$ & 0.42 \\
\hline
\end{tabular}

samples from an aluminium industry had been measured using gamma ray spectroscopy method. The radium equivalent activity $\left(\mathrm{Ra}_{\mathrm{eq}}\right)$, absorbed dose rate in air and the annual effective dose were calculated from the activity concentrations of ${ }^{226} \mathrm{Ra},{ }^{232} \mathrm{Th}$ and ${ }^{40} \mathrm{~K}$. The results of the $\mathrm{Ra}_{\mathrm{eq}}$ are within the recommended safety limit. The annual effective doses due to the samples are less than the recommended limit of $1 \mathrm{mSv} \cdot \mathrm{y}^{-1}$ to the general public. Hence the workers and the public are not at risk as far as radiological hazard is concerned. However the annual gonadal dose equivalent was higher than the world average value with the exception of alumina.

\section{REFERENCES}

[1] UNSCEAR, United Nation Scientific Committee on the Effect of Atomic Radiation, "Sources, Effects and Risk of Ionizing Radiation," New York, 2000.

[2] J. Beretka and P. J. Mathew, "Natural Radioactivity of Australian Building Materials, Industrial Wastes and Byproducts," Health Physics, Vol. 48, No. 1, 1985, pp. 87-95. http://dx.doi.org/10.1097/00004032-198501000-00007

[3] L. Bruzzi, M. Baroni, G. Mazzotti, R. Mele and S. Righi, "Radioactivity in Raw Materials and End Products in the Italian Ceramics Industry," Journal of Environmental Radioactivity, Vol. 47, No. 2, 2000, pp. 171-181. http://dx.doi.org/10.1016/S0265-931X(99)00026-0

[4] Th. Karagiannidi, H. Papaefthymiou and G. Papatheodorou, "Radioactive Impact of a Bauxite Beneficiation Plant in the Itea Gulf (Gulf of Corinth, Greece)," Journal of Radioanalytical and Nuclear Chemistry, Vol. 279, No. 3, 2009, pp. 923-934. http://dx.doi.org/10.1007/s10967-008-7412-3

[5] A. A. Fathivand and J. Amidi, "Natural Radioactivity Concentration in Raw Materials Used for Manufacturing Refractory Products," Radioprotection, Vol. 44, No. 5, 2009, pp. 265-268. http://dx.doi.org/10.1051/radiopro/20095051

[6] X. W. Lu and X. L. Zhang, "Measurement of Natural Radioactivity in Sand Samples Collected from Baoji Weihe Sands Park, China," Environmental Geology, Vol. 50, No. 7, 2006, pp. 977-982.

http://dx.doi.org/10.1007/s00254-006-0266-5

[7] N. N. Greenwood and A. Earnshaw, "Chemistry of the Elements," 2nd Edition, Butterworth-Heinemann Oxford, Oxford, 1997.

[8] EC, European Commission, "Effluent and Dose Control from European Union NORM Industries: Assessment of Current Situation and Proposal for a Harmonised Community Approach," Vol. 1, Main Report, Radiation Protection 135, Luxembourg, 2003.

[9] IAEA, International Atomic Energy Agency, "Extent of Environmental Contamination by Naturally Occurring Radioactive Material (NORM) and Technological Options for Mitigation," Technical Report, Series No. 49, Vienna, 2003.

[10] G. Papatheodorou, H. Papaefthymiou, A. Maratou and G. Ferentinos, "Natural Radionuclides in Bauxite Tailings (RedMud) in the Gulf of Corinth, Greece," Radioprotection, Vol. S1, No. 40, 2005, pp. S459-S555. http://dx.doi.org/10.1051/radiopro:2005s1-080

[11] A. S. Alencar and A. C. Freitas, "Reference Levels of Natural Radioactivity for Beach Sands in a Brazilian Southeastern Coastal Region," Radiation Measurements, Vol. 40, No. 1, 2005, pp. 76-83.

http://dx.doi.org/10.1016/j.radmeas.2004.08.003 
[12] I. P. Farai and J. A. Ademola, "Radium Equivalent Activity Concentrations in Concrete Building Blocks in Eight Cities in Southwestern Nigeria," Journal of Environmental Radioactivity, Vol. 79, No. 2, 2005, pp. 119-125. http://dx.doi.org/10.1016/j.jenvrad.2004.05.016

[13] L. Bruzzi, M. Baroni, G. Mazzott, R. Mele and S. Righi, "Radioactivity in raw materials and end products in the Italian Ceramic industry. Journal of Environmental Radioactivity, Vol. 47, No. 2, 2000, pp. 171-181. http://dx.doi.org/10.1016/S0265-931X(99)00026-0

[14] R. Krieger, "Radioactivity of Construction Materials," Betonwerk Fertigteil Technology, Vol. 47, No. 8, 1981, pp. 468-473.

[15] X. W. Lu and X. L. Zhang, ${ }^{\text {“226 }}{ }^{22},{ }^{232}$ Th and ${ }^{40} \mathrm{~K}$ Activities in Soil of Cuihna Mountain National Geological Park, China," Environmental Geology, Vol. 56, No. 2, 2008, pp. 353-357. http://dx.doi.org/10.1007/s00254-007-1170-3

[16] J. A. Ademola, "Assessment of Natural Radionuclide Content of Cement Used in Nigeria," Journal of Radiological Protection, Vol. 28, No. 4, 2008, pp. 581-588. http://dx.doi.org/10.1088/0952-4746/28/4/010

[17] OECD, Organization of Economic Cooperation and De- velopment, "Exposure to Radiation from Natural Radioactivity in Building Materials," Report by a Group of Experts of the OECD, Nuclear Energy Agency, Paris, 1979.

[18] R. Veiga, N. Sanches, R. M. Anjos, K. Macario, J. Bastos, M. Iguatemy, J. G. Aguiar, A. M. A. Santos, B. Mosquera, C. Carvalho, F. M. Baptista and N. K. Umisedo, "Measurement of Natural Radioactivity in Brazilian Beach Sands," Radiation Measurements, Vol. 41, No. 2, 2006, pp. 189196. http://dx.doi.org/10.1016/j.radmeas.2005.05.001

[19] ICRP, International Commission on Radiological Protection, "Recommendations of ICRP, Publication 60; Ann. ICRP 21," 1990, pp. 1-3.

[20] UNSCEAR, United Nation Scientific Committee on the Effect of Atomic Radiation, "Sources and Effects of Ionizing Radiation," New York, 1988.

[21] L. Xinwei, W. Lingqing, J. Xiaodan, Y. Leipeng and D. Gelian, "Specific Activity and Hazards of Archeozoic-Cambrian Rock Samples Collected from the Weibei Area of Shaanxi, China," Radiation Protection Dosimetry, Vol. 118, No. 3, 2006, pp. 352-359. http://dx.doi.org/10.1093/rpd/nci339 